\title{
New monitoring confirms regular breeding of the Mediterranean monk seal in Northern Cyprus
}

\author{
Damla Beton, Annette C. Broderick, Brendan J. Godley \\ Emre Kolaç, Meltem OK and Robin T. E. Snape
}

\begin{abstract}
The Endangered Mediterranean monk seal Monachus monachus is one of the most threatened marine mammals. Across Cyprus, suitable habitat and presence of monk seals is well documented and, recently, camera-trap surveys in Southern Cyprus found there to be pupping. We present results of the first camera-trap surveys in Northern Cyprus spanning the pupping period. Four adult/subadults and three pups were identified in three of eight caves monitored with camera traps. One site on the north-west of the island supported at least three adult/subadult seals and pupping occurred there in 3 consecutive years. The breeding and resting sites identified require urgent conservation to manage threats of disturbance, coastal development and fisheries bycatch. To determine the size of this population, a long-term survey with greater and more continuous coverage is required.
\end{abstract}

Keywords Breeding, camera trap, Cyprus, Mediterranean monk seal, Monachus monachus

$\mathrm{H}$ istorically, the Mediterranean monk seal Monachus monachus used open beaches for resting and breeding (González, 2015). However, in response to human pressures, pupping is now restricted to suboptimal sea cave habitats, and the species range has contracted substantially (Sergeant et al., 1978; Dendrinos et al., 2010). Exploitation (Stringer et al., 2008), persecution, disturbance, habitat loss (Karamanlidis et al., 2004, 2016a) and fisheries bycatch (Karamanlidis et al., 2008) have all contributed to the decline of the species, and it is categorized as Endangered on the IUCN Red List (Karamanlidis \& Dendrinos, 2015).

Monk seals have long been known to occur in Cyprus, where sightings have been relatively common (Bundone

DAmla Beton (Corresponding author, (D) orcid.org/0000-0002-6305-7667) North Cyprus Society for Protection of Turtles, PK.65, Kyrenia, North Cyprus (Mersin 10/Turkey). E-mail damlabeton@gmail.com

Annette C. Broderick, Brendan J. Godley and Robin T. E. Snape* Centre for Ecology and Conservation, College of Life and Environmental Sciences, University of Exeter, Penryn Campus, Penryn, UK

EmRe Kolaç DeepWorx Underwater Salvage \& Construction, Nicosia, North Cyprus

Мецтем Ок Department of Marine Biology and Fisheries, Middle Eastern Technical University, Erdemli, Turkey

*Also at: North Cyprus Society for Protection of Turtles, Kyrenia, North Cyprus

Received 20 February 2020. Revision requested 7 April 2020.

Accepted 17 August 2020. First published online 2 March 2021. et al., 2019). In Southern Cyprus, Dendrinos \& Demetropoulos (2000) described 18 caves, with four suitable for breeding. Systematic monitoring was established in 2011, and 14 seals have since been identified, including five pups (Nicolaou et al., 2019). In Northern Cyprus, Gucu et al. (2009) described 39 caves, with eight suitable for breeding, and five seals were identified outside the breeding season. Single adult seals were found stranded dead in 2012 and 2014 (Snape et al., 2014), and a non-moulted pup was observed with an adult female in 2013 (Snape et al., 2013; for standardization, we use the age-sex classification of Samaranch \& González, 2000).

Here, towards establishing long-term population monitoring in Northern Cyprus, three previously confirmed (Gucu et al., 2009) and five potential monk seal haul-out caves (Fig. 1), were monitored intermittently using motion-activated infrared camera traps during November 2016-May 2019. Camera traps, anchored to the walls of caves, were configured to take still images with a 20 minute delay between subsequent photograph events. Where possible, seals were uniquely identified using body scars.

The study caves (Fig. 1) were monitored for a total of 1,619 days (Fig. 2). Seals were confirmed on 63, 4 and 1 days at caves YD1, ZB6 and ZB9, respectively (Table 1). Seven seals were uniquely identified from the resulting 2,740 images of monk seals: three pups (Class O: non-moulted pup) and four juvenile-subadult-adult seals (Class B-C: i.e. all were post-neonatal moult and varying in size, see below). One seal was not identifiable as unique from the others, but may have been an additional individual (Class C; Plates 1 \& 2).

Births were recorded in cave YD1 during 2016-2017 and also a pup observed on the coast in 2018 was likely born in this cave or a nearby site. Pup 1 (sex unknown) was recorded during 25 November-9 December 2016 and a moulted pup (Class A) observed on 11 February 2017 outside the cave is considered to be this pup. Pup 2 (female) was recorded on 11 November 2017 but died at Class O. Strong storms drove waves into the back of the cave, and the mother was observed defending the pup as the water level in the cave rose. Following the storms, the healthy mother was recorded at the camera trap but the pup was not. The skull of Pup 2 was found during the following field survey in the cave and cause of death was thus attributed to the effects of wave action (Androukaki et al., 1999), based on the combined circumstantial evidence. Pup 3 (male) was not 


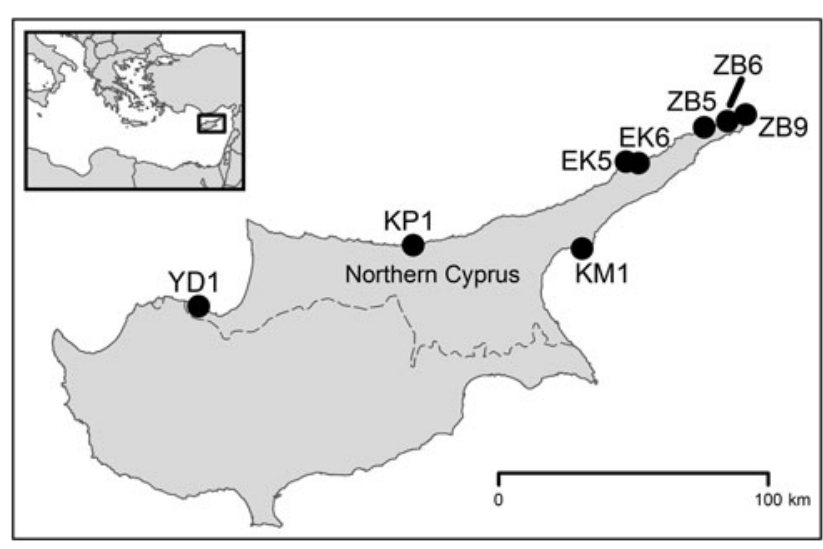

FIG. 1 Location of caves around the coast of Northern Cyprus monitored by camera traps for the Mediterranean monk seal Monachus monachus during 2016-2019.

photographed by the camera trap but observed as Class $\mathrm{O}$ at a fishing harbour east of cave YD1 on 27 October 2018, following a storm. The status of this pup was monitored until 31 October, when a Class C (subadult/adult) seal was seen in the area and the pup disappeared from surveillance. However, on 5 November, after further heavy seas, a pup assumed to be Pup 3 was found dead on a beach $9 \mathrm{~km}$ from cave YD1. Seal 1 (Class C: adult, female) was the mother of Pups 1 and 2 and probably Pup 3, as it was again photographed in cave YD1 during the 2018 breeding season. The birth and suckling of Pup 3 may have occurred in an area of the cave not covered by the camera trap, in a nearby cave, or on an open beach where it rested during surveillance.

Seal 2 (Class B: juvenile/subadult, female) used cave YD1 in 2016-2017. Seal 3 (Class C, sex unknown) was photographed in 2018 in cave YD1. Seal 4 (Class C, female) was photographed in cave ZB9 on 10 October 2018. A further unidentified seal (considered Class $\mathrm{C}$ ) was observed briefly during 2018 at cave ZB6.

Until recently, Cyprus was considered part of the historical range of the Mediterranean monk seal (Karamanlidis et al., 2008), but was not listed within the four main regions for conservation priority and action developed in a recent review (Karamanlidis et al., 2016a). Although our study was limited in its coverage and continuity (Figs 1 \& 2), four Class B and C seals were individually identified and persistent annual breeding was confirmed. Given that monitoring in Southern Cyprus has also confirmed regular breeding (Nicolaou et al., 2019), the island is clearly important for the species. The eastern Mediterranean population is in the low hundreds of individuals, with reduced genetic diversity (Karamanlidis et al., 2016b), and thus extensive and continuous monitoring and conservation, across all of Cyprus, is a priority.

All three active caves were previously classified as such by Gucu et al. (2009). The Yeşilırmak/Limnitis region (Cave YD1) is an annual breeding site and hosted at least three of the Class B-C individuals, demonstrating its importance as a focal point for the population. Although the suitability of the cave for breeding appears low, with just one of three monitored pups surviving to post-moulting, the coast east of the cave includes inaccessible beaches where Pup 3 was observed to haul out and rest. These could be important supporting habitats (Dendrinos et al., 2010). Monitoring of other caves was carried out only during the 2018 pupping season, when weather conditions were particularly inclement, resulting in some data loss as a result of damage to camera traps. Gucu et al. (2009) considered some of these sites to have the greatest potential for seal use and continued monitoring of those caves is therefore important, despite the low use reported here.

All the caves with evidence of monk seal use should be incorporated into the national network of Specially Protected Areas, with appropriate access, development and fisheries restrictions to mitigate human disturbance, habitat loss and bycatch. Development around all suitable caves should be prohibited completely, with buffer zones around caves to include restricted access to nearby coastal stretches where seals are likely to be encountered. Such

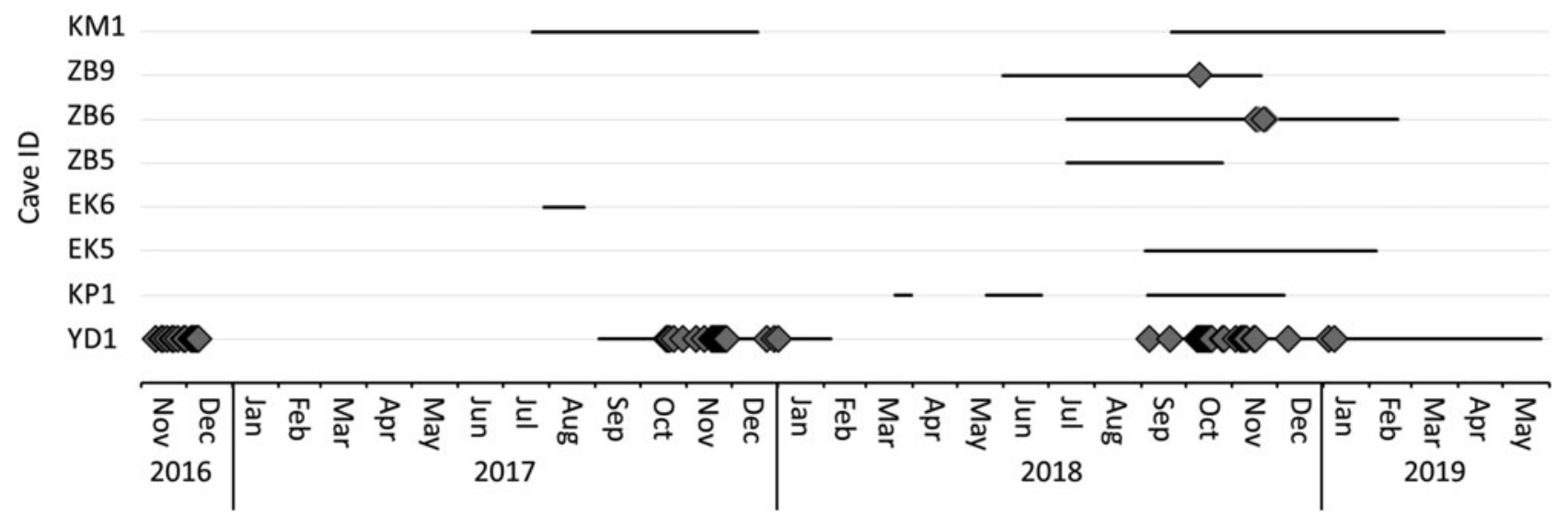

FIG. 2 Camera trap monitoring periods (black horizontal line) and days on which Mediterranean monk seals were detected (diamonds), from November 2016 to May 2019. 
TABLE 1 Summary of monitoring days and days on which seals were detected at active caves monitored during the Mediterranean monk seal Monachus monachus breeding seasons of 2016-2018.

\begin{tabular}{|c|c|c|c|c|c|c|c|c|c|c|}
\hline \multirow[b]{3}{*}{ Cave } & \multirow[b]{3}{*}{ Breeding season } & \multirow[b]{3}{*}{ No. of days monitored } & \multicolumn{8}{|c|}{ No. of days with detections } \\
\hline & & & \multirow[b]{2}{*}{ Total } & \multicolumn{2}{|c|}{ Pup $^{1}$} & \multicolumn{4}{|c|}{ Seal $^{1}$} & \multirow[b]{2}{*}{ Unidentified } \\
\hline & & & & 1 & 2 & 1 & 2 & 3 & 4 & \\
\hline \multirow[t]{3}{*}{ YD1 } & 2016 & 36 & 15 & 8 & & 11 & 5 & & & \\
\hline & 2017 & 156 & 21 & & 2 & 15 & 2 & & & 5 \\
\hline & 2018 & 263 & 27 & & & 14 & & 5 & & 10 \\
\hline ZB6 & 2018 & 222 & 4 & & & & & & & 4 \\
\hline ZB9 & 2018 & 174 & 1 & & & & & & 1 & \\
\hline
\end{tabular}

${ }^{1}$ Pups 1 and 2, and Seals 1, 2, 3 and 4 are individuals identified through camera traps.
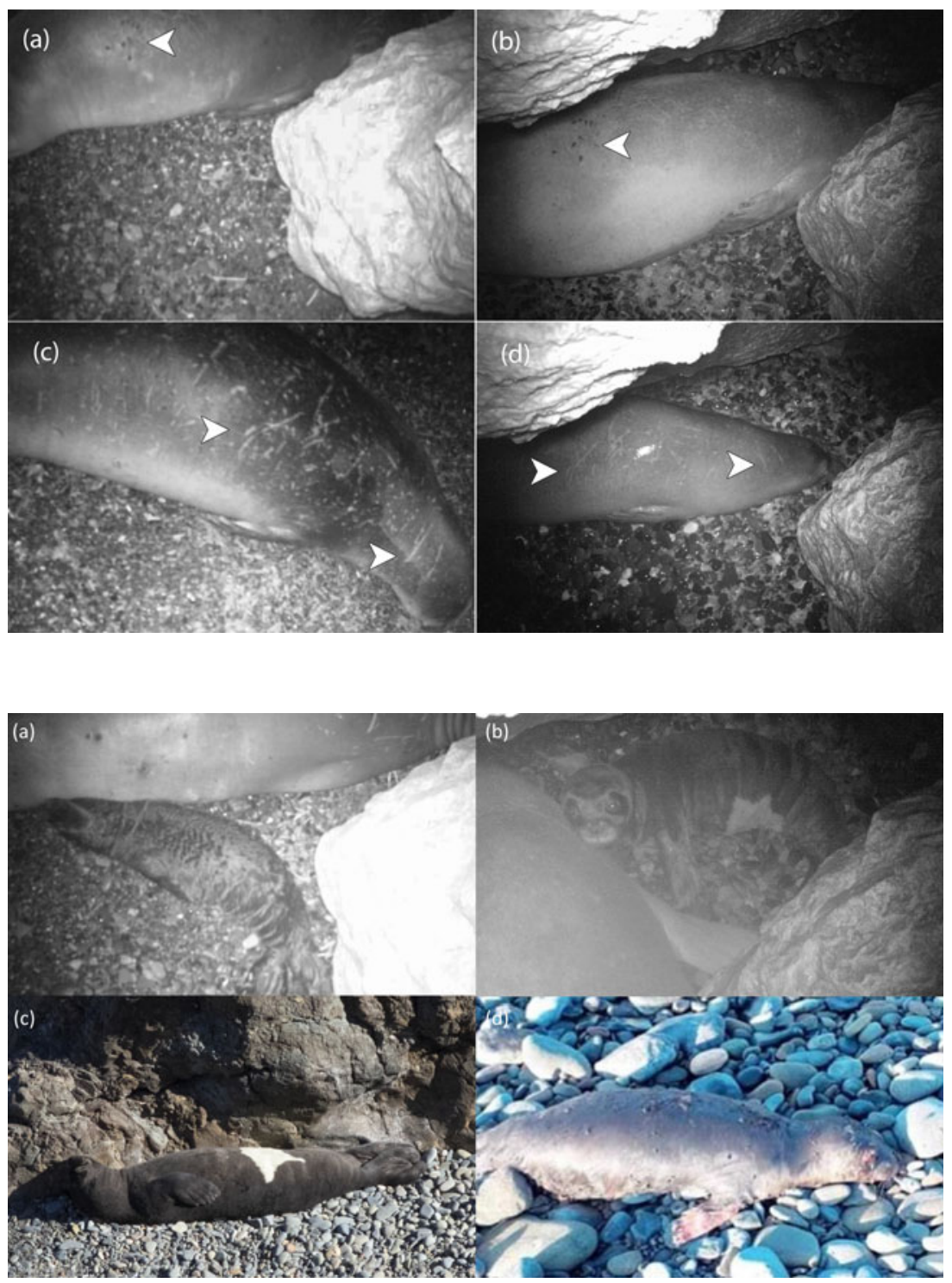

Plate 1 Camera-trap photographs of Seal 1, which gave birth to Pups 1 and 2 at cave YD1 (Fig. 1) in (a) 2016 and (b) 2017, and of Seal 2 in 2016 (c) and 2017 (d) in cave YD1. Scars used for identification are indicated by arrows.
Plate 2 Camera-trap photographs of (a) Pup 1, which survived to post-moulting, and (b) Pup 2, which died before moulting, and images of (c) Pup 3 during monitoring (Photo: Olkan Ergüler), and (d) pup assumed to be Pup 3, stranded (Photo: Adem Kervanli). measures could potentially encourage seals to return to suitable caves, such as $\mathrm{ZB} 9$ and $\mathrm{KM} 1$, which were used less than expected. Marine reserves in Greece and Madeira have banned fishing within three nautical miles of pupping caves and to the $100 \mathrm{~m}$ isobath, respectively (Karamanlidis et al., 2008). Such measures may be ambitious, given established artisanal fisheries (Snape et al., 2018). A vessel tracking study has shown that fishers regularly set nets around the 
caves (Snape, 2018). Appropriate compromises could be reached through the introduction of small-scale fisheries comanagement (Carlsson \& Berkes, 2005).

Acknowledgements We thank Ali Cemal Gücü at Middle East Technical University for his collaboration, contributions and support, the MAVA Foundation for the provision of two grants for the 2018-2019 season and beyond, the Northern Cyprus Department of Animal Husbandry, Northern Cyprus Environmental Protection Department, and the Editor and two anonymous referees for constructive suggestions.

Author contributions Study design: DB, EK, MO, RTES, BJG; fieldwork: DB, EK; data analysis: DB; writing: all authors.

\section{Conflicts of interest None.}

Ethical standards This research abided by the Oryx guidelines on ethical standards.

\section{References}

Androukaki, E., Adamantopoulou, S., Dendrinos, P., Tounta, E. \& Котоматаs, S. (1999) Causes of mortality in the Mediterranean monk seal (Monachus monachus) in Greece. Contributions to the Zoogeography and Ecology of the Eastern Mediterranean Region, $1,405-411$.

Bundone, L., Panou, A. \& Molinaroli, E. (2019) On sightings of (vagrant?) monk seals, Monachus monachus, in the Mediterranean Basin and their importance for the conservation of the species. Aquatic Conservation Marine and Freshwater Ecosystems, 29, 554-563.

Carlsson, L. \& Berkes, F. (2005) Co-management: concepts and methodological implications. Journal of Environmental Management, 75, 65-76.

Dendrinos, P. \& Demetropoulos, A. (2000) The Mediterranean monk seal in Cyprus. Monachus Guardian, 3, 75-77.

Dendrinos, P., Karamanlidis, A.A., Kotomatas, S., Paravas, V. \& Adamantopoulou, S. (2010) Report of a new Mediterranean monk seal (Monachus monachus) breeding colony in the Aegean Sea, Greece. Aquatic Mammals, 34, 355-361.

Gonzalez, L.M. (2015) Prehistoric and historic distributions of the Critically Endangered Mediterranean monk seal (Monachus monachus) in the eastern Atlantic. Marine Mammal Science, 31, 1168-1192.

GUCU, A.C., OK, M. \& SAKINAN, S. (2009) A survey of the Critically Endangered Mediterranean monk seal, Monachus monachus (Hermann, 1779) along the coast of Northern Cyprus. Israel Journal of Ecology and Evolution, 55, 77-82.
Karamanlidis, A.A., Androukaki, E., Adamantopoulou, S., Chatzispyrou, A., Johnson, W.M., Kotomatas, S. et al. (2008) Assessing accidental entanglement as a threat to the Mediterranean monk seal Monachus monachus. Endangered Species Research, 5, 205-213.

Karamanlidis, A. \& Dendrinos, P. (2015) Monachus monachus (errata version published in 2017). In The IUCN Red List of Threatened Species 2015: e.T13653A117647375. dx.doi.org/10.2305/ IUCN.UK.2015-4.RLTS.T13653A45227543.en [accessed 2 October 2020].

Karamanlidis, A.A., Dendrinos, P., de Larrinoa, P.F., Gücư, A.C., Johnson, W.M., Kiraç, C.O. \& Pires, R. (2016a) The Mediterranean monk seal Monachus monachus: status, biology, threats, and conservation priorities. Mammal Review, 46, 92-105.

Karamanlidis, A.A., Gaughran, S., Aguilar, A., Dendrinos, P., Huber, D., Pires, R. et al. (2016b) Shaping species conservation strategies using mtDNA analysis: The case of the elusive Mediterranean monk seal (Monachus monachus). Biological Conservation, 193, 71-79.

Karamanlidis, A.A., Pires, R., Silva, N.C. \& Neves, H.C. (2004) The availability of resting and pupping habitat for the Critically Endangered Mediterranean monk seal Monachus monachus in the archipelago of Madeira. Oryx, 38, 180-185.

Nicolaou, H., Dendrinos, P., Marcou, M., Michaelides, S. \& Karamanlidis, A.A. (2019) Re-establishment of the Mediterranean monk seal Monachus monachus in Cyprus: priorities for conservation. Oryx, published online 23 December 2019.

Samaranch, R. \& GonZalez, L.M. (2000) Changes in morphology with age in Mediterranean monk seals (Monachus monachus). Marine Mammal Science, 16, 141-157.

Sergeant, D., Ronald, K., Boulva, J. \& Berkes, F. (1978) Recent status of Monachus monachus the Mediterranean monk seal. Biological Conservation, 14, 259-287.

SNAPE, R.T.E. (2018) Investigating conflict between threatened marine megavertebrates and Mediterranean small-scale fisheries. $\mathrm{PhD}$ thesis, University of Exeter, Exeter, UK.

Snape, R.T.E., Bradshaw, P., Fuller, W.J., Godley, B.J. \& Broderick, A.C. (2014) Marine Turtle Conservation Project Northern Cyprus. Annual report 2014, Nicosia, Cyprus.

Snape, R.T.E., Broderick, A.C., Çıçek, B.A., Fuller, W.J., Tregenza, N., Witt, M.J. \& Godley, B.J. (2018) Conflict between dolphins and a data-scarce fishery of the European Union. Human Ecology, 46, 423-433.

Snape, R.T.E., Rhodes, K.A., Fuller, W.J., Godley, B.J. \& Broderick, A.C. (2013) Marine Turtle Conservation Project Northern Cyprus. Annual report 2013, Nicosia, Cyprus.

Stringer, C.B., Finlayson, C., Barton, N. \& Jalvo, Y.F. (2008) Neanderthal exploitation of marine mammals in Gibraltar. Proceedings of the National Academy of Sciences of the United States of America, 105, 14319-14324. 